\title{
Hypoactivity of the Spinal Cannabinoid System Results in NMDA-Dependent Hyperalgesia
}

\author{
Jennelle Durnett Richardson, ${ }^{1}$ Lin Aanonsen, ${ }^{3}$ Kenneth M. Hargreaves ${ }^{1,2}$ \\ Departments of ${ }^{1}$ Pharmacology and ${ }^{2}$ Restorative Sciences, University of Minnesota, Minneapolis, Minnesota 55455, and \\ ${ }^{3}$ Department of Biology, Macalester College, St. Paul, Minnesota 55105
}

Cannabinoids, such as $\Delta^{9}$-THC, are capable of inhibiting nociception, i.e., pain transmission, at least in part, by interacting with spinal $G_{i} / G_{0}$-coupled cannabinoid receptors. What is not known, however, is the antinociceptive role of endogenous spinal cannabinoids. If endogenous cannabinoids modulate basal nociceptive thresholds, then alterations in this system could be involved in the etiology of certain pain states. In this report we provide evidence for tonic modulation of basal thermal nociceptive thresholds by the spinal cannabinoid system. Administration of oligonucleotides directed against $\mathrm{CB}_{1}$ cannabinoid receptor mRNA significantly reduced spinal cannabinoid binding sites and produced significant hyperalgesia when compared with a randomer oligonucleotide control. A second method used to reduce activity of the spinal cannabinoid re- ceptor was intrathecal administration of the cannabinoid receptor antagonist SR 141716A. SR 141716A evoked thermal hyperalgesia with an $\mathrm{ED}_{50}$ of $0.0012 \mathrm{fmol}$. The SR 141716Ainduced hyperalgesia was dose-dependently blocked by the administration of D-AP-5 or MK-801, two antagonists to the NMDA receptor. These results indicate that there is tonic activation of the spinal cannabinoid system under normal conditions. Furthermore, hypoactivity of the spinal cannabinoid system results in an NMDA-dependent hyperalgesia and thus may participate in the etiology of certain chronic pain states.

Key words: endogenous cannabinoid; SR 141716A; glutamate; NMDA; hyperalgesia; nociceptive threshold; tonic; spinal cord
Antinociception induced by administration of exogenous cannabinoids has been widely reported. Available evidence supports the hypothesis that the antinociception induced by intrathecal administration of cannabinoids is mediated, at least in part, via activation of receptors located in the spinal cord. Autoradiographic studies have identified cannabinoid receptors localized within the dorsal horn of the spinal cord in regions known to receive input from nociceptors (Herkenham et al., 1991). Cannabinoid administration can prevent the expression of c-fos in the dorsal horn (Tsou et al., 1996) and inhibit the firing of wide dynamic range neurons (Hohmann et al., 1995) in response to noxious stimuli. Additionally, antinociception induced by either intravenous or intrathecal administration of the synthetic cannabinoid CP 55,940 persists after spinal transection (Lichtman and Martin, 1991), indicating that descending control from supraspinal sites cannot completely account for cannabinoid-mediated antinociception. Collectively, these data indicate that cannabinoids have a spinal site of action for at least some of their antinociceptive effects.

Although there is a large body of evidence that exogenously applied cannabinoids in normal animals are capable of producing antinociception, the role of endogenous cannabinoids in modulating basal nociceptive thresholds is not well understood. Many spinal antinociceptive systems do not seem to modulate basal

Received July 25, 1997; revised Oct. 3, 1997; accepted Oct. 8, 1997.

This work was supported by a predoctoral grant from the Howard Hughes Medical Institute (J.D.R.) and by National Institutes of Health Grant DE9860 (K.M.H.). SR

141716A was a gift from Sanofi Recherche (Montpellier, France). We thank M. A. Sabino for technical assistance.

Correspondence should be addressed to Dr. Ken Hargreaves, Department of Endodontics, Dental School, University of Texas Health Science Center, 7703 Floyd Curl Drive, San Antonio, TX 78284.

Dr. Richardson's present address: Department of Neurobiology, Harvard Medical School, Boston, MA 02115.

Copyright (C) 1997 Society for Neuroscience $\quad 0270-6474 / 97 / 180451-07 \$ 05.00 / 0$ nociceptive thresholds but are invoked only in response to nociceptive stimuli. For example, intrathecal administration of naloxone does not produce a consistent effect on nociceptive responses (Besson and Chaouch, 1987). Additionally, animals that lack the $\mu$ opioid receptor subtype show little, if any, change in basal thermal nociceptive thresholds (Sora et al., 1997). These studies indicate that the spinal opioid receptors have, at most, a limited role in modulating basal thermal nociceptive thresholds. The question of whether a system modulates basal nociceptive thresholds is important because hypoactivity of such a system could be involved in the etiology of hyperalgesic states. Accordingly, understanding the mechanism responsible for the transition to hyperalgesia is important for the development of novel therapeutic drugs.

The mechanism by which spinal cannabinoids produce antinociception is not well understood but may stem from their ability to inhibit the release of neurotransmitters. Cannabinoids have been reported to inhibit electrically evoked acetylcholine release from hippocampal slices (Gifford and Ashby, 1996), norepinephrine release from sympathetic nerves (Ishac et al., 1996), and glutamate release from hippocampal cultures (Shen et al., 1996). In addition to the hippocampus, glutamate is located in terminals in the spinal cord (De Biasi and Rustioni, 1988), and its intrathecal application results in hyperalgesia (Aanonsen and Wilcox, 1987). Thus, inhibition of glutamate release into the spinal cord is one potential mechanism for the antinociceptive effects of cannabinoids.

The purpose of the present study was to evaluate the hypothesis that the spinal endogenous cannabinoid system modulates basal nociceptive thresholds and that hypoactivity of this system results in hyperalgesia. The mouse hot plate assay was used to measure hyperalgesia to thermal stimuli. First, the effects of the administration of a selective $\mathrm{CB}_{1}$ cannabinoid receptor antisense 
oligonucleotide were determined on both cannabinoid receptor density and hot plate latencies. Next, we evaluated the effects of administration of a selective $\mathrm{CB}_{1}$ cannabinoid receptor antagonist on hot plate latencies. Finally, we determined whether the observed hyperalgesia was mediated by the NMDA receptor.

\section{MATERIALS AND METHODS}

Animals. Male ND4 Swiss mice (20-25 gm; Harlan Laboratories, Indianapolis, IN) were maintained on a $12 \mathrm{hr}$ light/dark cycle with free access to food and water. All procedures were approved by the University of Minnesota Animal Care and Use Committee.

Materials. Materials were obtained from the following companies: oligonucleotides, Microchemical Facilities (University of Minnesota, Minneapolis, MN); $\left[{ }^{3} \mathrm{H}\right] \mathrm{CP} 55,940$, DuPont NEN (Boston, MA); SR 141716A [ $N$-(piperidin-1-yl)-5-(4-chlorophenyl)-1(2,4-dichlorophenyl)-4methyl-1 H-pyrazole-3-carboxyamide], a gift from Sanofi Recherche (Montpellier, France); [ $\left.{ }^{3} \mathrm{H}\right] \mathrm{SR}$ 141716A, Amersham (Arlington Heights, IL); MK-801, RBI (Natick, MA); AP-5, Tocris Cookson (Ballwin, MO); sterile saline, Baxter (McGaw Park, IL); UltimaGold scintillation cocktail, Packard (Meriden, CT). All other reagents were purchased from Sigma (St. Louis, MO).

Intrathecal injections. Intrathecal injections were performed as described by Hylden and Wilcox (1980). Briefly, a 30 gauge needle was inserted into the subarachnoid space approximately between vertebrae L5 and L6. Successful placement was indicated by a prototypic tail flick reflex. All drugs were injected in a volume of $5 \mu \mathrm{l}$ in a saline vehicle. SR $141716 \mathrm{~A}$ was initially solubilized in ethanol and then diluted in saline, with a final ethanol concentration of $<0.00001 \%$.

Oligonucleotide treatment. Mice received a $12.5 \mu \mathrm{g}$ intrathecal injection once a day for $4 \mathrm{~d}$ of either an 18-mer oligonucleotide complementary to bases 4-21 of the $\mathrm{CB}_{1}$ receptor mRNA ("antisense") or an 18-mer randomer control showing identical $\mathrm{G} / \mathrm{C}$ composition but not complementary to any known mRNA (Edsall et al., 1996).

$P_{2}$ membrane preparation. Animals were decapitated, and their spinal cords were removed via hydraulic extrusion. The lumbar and cervical enlargements were dissected and immediately frozen on dry ice. $\mathrm{P}_{2}$ membranes were prepared using the method described by Devane et al. (1988). Briefly, tissue was pooled and homogenized in $30 \mathrm{ml}$ of sucrose (320 mM), EDTA $(2 \mathrm{~mm})$, and $\mathrm{MgCl}_{2}(5 \mathrm{~mm})$, and then centrifuged at $2000 \times g$ for $10 \mathrm{~min}$. The pellet was washed twice. The supernatants were then centrifuged at $39,000 \times g$ for $15 \mathrm{~min}$. The pellet was resuspended in $30 \mathrm{ml}$ buffer A [Tris- $\mathrm{HCl}\left(50 \mathrm{~mm}, \mathrm{pH} 7.0\right.$, at $\left.30^{\circ} \mathrm{C}\right)$, EDTA $(2 \mathrm{~mm})$, and $\left.\mathrm{MgCl}_{2}(5 \mathrm{mM})\right]$ at $37^{\circ} \mathrm{C}$ for $10 \mathrm{~min}$. This was centrifuged at $23,000 \times \mathrm{g}$ for $10 \mathrm{~min}$. The pellet was resuspended in $30 \mathrm{ml}$ buffer $\mathrm{A}$ at $30^{\circ} \mathrm{C}$ for $40 \mathrm{~min}$. This was centrifuged at $11,000 \times g$ for $15 \mathrm{~min}$. The pellet was resuspended in $1 \mathrm{ml}$ Tris- $\mathrm{HCl}\left(50 \mathrm{~mm}, \mathrm{pH} 7.4\right.$, at $\left.30^{\circ} \mathrm{C}\right)$, EDTA $(1 \mathrm{~mm})$, and $\mathrm{MgCl}_{2}(3 \mathrm{~mm})$, and stored at $-80^{\circ} \mathrm{C}$.

Radioreceptor binding. Homogenates [60 or $100 \mu \mathrm{g}$ of protein, determined by the Bradford assay using Sigma fatty acid-free bovine serum albumin (BSA) as the standard] were incubated for $1 \mathrm{hr}$ at room temperature in assay buffer [Tris-HCl $(50 \mathrm{~mm}, \mathrm{pH} 7.4), \mathrm{MgCl}_{2}(3 \mathrm{~mm})$, EDTA $(1 \mathrm{~mm})$, and fatty acid-free BSA $(1 \mathrm{mg} / \mathrm{ml})]$ with various concentrations of the cannabinoid receptor agonist $\left[{ }^{3} \mathrm{H}\right] \mathrm{CP}-55940$ or the cannabinoid receptor antagonist $\left[{ }^{3} \mathrm{H}\right] \mathrm{SR}$ 141716A. Total volume per reaction tube was $200 \mu \mathrm{l}$. Nonspecific binding was determined with unlabeled SR 141716A $(1 \mu \mathrm{M})$. The reaction was terminated with rapid filtration over a Whatman GF/C filter (Hillsboro, OR) that had been soaked for 15 $\min$ in $0.5 \%$ polyethylenimine. Tissue was then washed three times with $4 \mathrm{ml}$ of ice-cold assay buffer. After they were washed, filters were transferred to a scintillation vial, and UltimaGold scintillation cocktail was added. Disintegrations per minute were determined by counting the vials with a liquid scintillation counter for $1 \mathrm{~min}$. Binding to tissue from animals in the knockdown experiment consisted of two separate experiments, each in triplicate, using homogenates of tissue from 10-15 animals. Binding to tissue from naive animals with $\left[{ }^{3} \mathrm{H}\right] \mathrm{SR} 141716 \mathrm{~A}$ consisted of two separate experiments, each in triplicate, using homogenates of tissue from 15-30 animals.

Hot plate latencies. Mice were placed on a Harvard Hot Plate Analgesia Meter (Edinbridge, $\mathrm{KY}$ ) set at $54-55^{\circ} \mathrm{C}$ and immediately removed when a response to the thermal noxious stimulus, either licking of a hindpaw or jumping from the surface of the hot plate, was observed. A $40 \mathrm{sec}$ cutoff was used to prevent tissue damage. Hot plate latencies were recorded in triplicate for each animal, with $\sim 5$ min separating each trial. The average baseline latency is $17.6 \pm 0.2 \mathrm{sec}$ (mean $\pm \mathrm{SEM} ; n=364$ ). Average baseline latencies were similar between the different treatment groups. After baseline latencies were recorded, a $5 \mu$ intrathecal injection of the appropriate drug was administered to the animals. In the studies using oligonucleotides, postinjection latencies were recorded on the day after the final injection immediately before collection of the tissue for radioreceptor binding studies. In the studies using SR 141716A, postinjection latencies were recorded $5 \mathrm{~min}$ after drug administration. Difference scores were determined for each mouse by subtracting its average baseline latency from its average postinjection latency. When blocked results were analyzed across different days of testing, inter-day experimental variability was removed by subtracting the vehicle control from the experimental group. The injector and hot plate observer were blind to treatment allocations.

Statistics. Receptor binding results were analyzed with GraphPad Prism software (San Diego, CA). $K_{\mathrm{d}}$ and $B_{\max }$ values were determined with nonlinear regression, and one-site and two-site analyses were compared to determine the better fit. Pharm/PCS software was used to calculate the $\mathrm{ED}_{50}$ values. Other data were analyzed either with Student's $t$ test or with ANOVA followed by a post hoc test, as appropriate. Results were considered significant when the probability that they occurred because of chance alone was $<5 \%$ (i.e., $p<0.05$ ). Data are reported as mean \pm SEM.

\section{RESULTS}

If the cannabinoid system is tonically active in modulating basal thermal nociceptive thresholds, then a decrease in cannabinoid receptor number should produce hypoactivity and thus hyperalgesia. To test this hypothesis, we used the "receptor knockdown" technique. Animals received an intrathecal injection of either the antisense or randomer oligonucleotide once a day for four consecutive days. Hot plate latencies were recorded before injection and on the day after termination of the injections. After the animals were tested, the lumbar and cervical enlargements of the spinal cord were collected and processed for receptor binding. There were no differences in the $K_{\mathrm{d}}$ values, regardless of treatment. However, as indicated in Figure 1 and Table 1, application of the antisense oligonucleotide produced a significant decrease in the amount of cannabinoid receptor binding in the lumbar enlargement when compared with the randomer oligonucleotide control $(0.62 \pm 0.15$ vs $1.58 \pm 0.19 \mathrm{pmol} / \mathrm{mg}$ protein $)$. Application of the randomer oligonucleotide produced no change in cannabinoid receptor levels in the lumbar enlargement when compared with animals receiving the same regimen of saline injections (Table 1). There were also no differences in cannabinoid receptor levels in the cervical enlargement regardless of treatment (Table 1 ), indicating that the $\mathrm{CB}_{1}$ antisense treatment selectively reduced cannabinoid receptors localized in the lumbar enlargement of the spinal cord.

After $4 \mathrm{~d}$ of receiving intrathecal oligonucleotide injections, animals receiving the $\mathrm{CB}_{1}$ antisense oligonucleotide demonstrated significant hyperalgesia when compared with the random controls $(-3.5 \pm 1.2$ vs $-0.3 \pm 0.7 \mathrm{sec}$ ) (Fig. 1). This effect corresponds with the decrease in cannabinoid receptor binding, which is consistent with the hypothesis that a decrease in $\mathrm{CB}_{1}$ receptors in the lumbar spinal cord results in the development of thermal hyperalgesia.

An additional series of studies independently tested the hypothesis that endogenous cannabinoids modulate basal nociceptive thresholds. We first determined that the $\mathrm{CB}_{1}$ receptor antagonist $\left[{ }^{3} \mathrm{H}\right] \mathrm{SR} 141716 \mathrm{~A}$ bound to the mouse lumbar spinal cord with a $K_{\mathrm{d}}$ of $600 \pm 200 \mathrm{pM}$ and a $B_{\max }$ of $0.8 \pm 0.1 \mathrm{pmol} / \mathrm{mg}$ protein (Fig. 2). We then determined whether an intrathecal injection of SR 141716A could evoke thermal hyperalgesia. If the cannabinoid receptor is tonically active, then administration of a cannabinoid receptor antagonist would be expected to block basal cannabinoid activity, resulting in hyperalgesia. The results are 
A

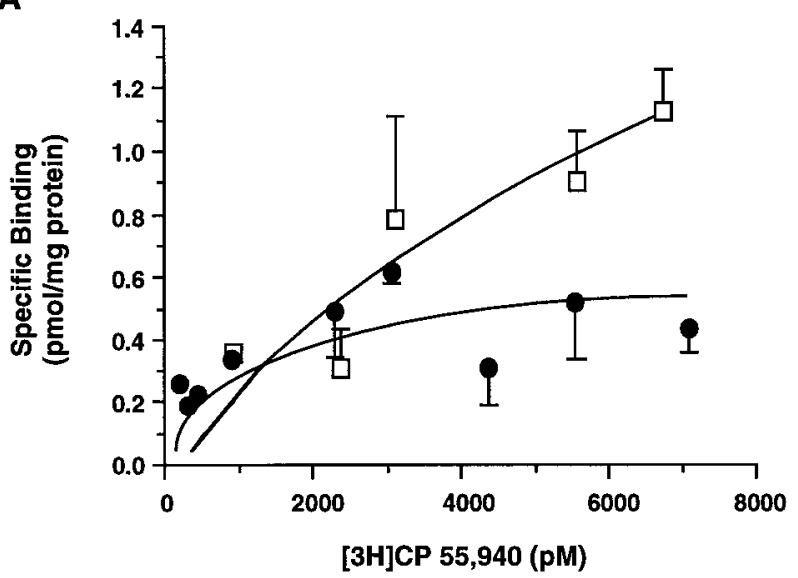

B

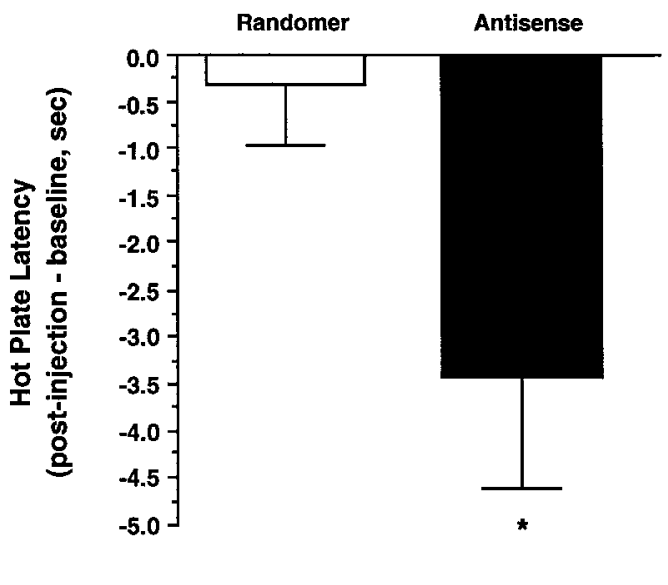

Figure 1. Effects of intrathecal administration of an antisense oligonucleotide complementary to the $\mathrm{CB}_{1}$ receptor mRNA on cannabinoid receptor binding $(A)$ and hyperalgesia $(B)$. $A$, Binding of the cannabinoid receptor agonist $\left[{ }^{3} \mathrm{H}\right] \mathrm{CP} 55,940$ to tissue from animals receiving the randomer control is represented by the open squares $\left(B_{\max }=1.6 \pm 0.2 \mathrm{pmol} / \mathrm{mg}\right.$ protein). Binding of the cannabinoid receptor agonist [ $\left.{ }^{3} \mathrm{H}\right] \mathrm{CP} 55,940$ to tissue from animals receiving the antisense oligonucleotide is represented by the filled circles $\left(B_{\max }=0.6 \pm 0.2 \mathrm{pmol} / \mathrm{mg}\right.$ protein). Error bars are SEM $(B)$. Hot plate latencies were recorded before injection on the first day of oligonucleotide treatment and before tissue collection 24 hr after the last oligonucleotide injection. Observers were blind to treatment allocations. $n=12-15$. Error bars are SEM. * $p<0.05$ (Student's $t$ test).

Table 1. Effect of various treatments on maximal $\left[{ }^{3} \mathrm{H}\right] \mathrm{CP} 55,940$

binding to mouse lumbar and cervical spinal cord

\begin{tabular}{lll} 
Treatment & $\begin{array}{l}\text { Lumbar spinal cord } \\
B_{\max }(\mathrm{pmol} / \mathrm{mg} \text { pro- } \\
\text { tein } \pm \mathrm{SEM})\end{array}$ & $\begin{array}{l}\text { Cervical spinal cord } \\
B_{\max }(\mathrm{pmol} / \mathrm{mg} \text { pro- } \\
\text { tein } \pm \mathrm{SEM})\end{array}$ \\
\hline Antisense & $0.62 \pm 0.15^{*}$ & $1.13 \pm 0.44$ \\
Randomer & $1.58 \pm 0.19$ & $1.08 \pm 0.30$ \\
Saline & $1.10 \pm 0.22$ & $1.18 \pm 0.15$
\end{tabular}

Lumbar: ${ }^{*} p<0.05$ vs randomer only; $\operatorname{ANOVA}\left(F_{(2,20)}=5.2\right)$; cervical: $p=\mathrm{ns}$; $\operatorname{ANOVA}\left(F_{(2,18)}=0.03\right)$.

presented in Figure 3. Animals injected with SR 141716A demonstrated a dose-dependent hyperalgesia $5 \mathrm{~min}$ after injection with an $\mathrm{ED}_{50}$ of $0.0012 \mathrm{fmol} / 5 \mu \mathrm{l}(0.24 \mathrm{pM})$ and a $95 \%$ confidence interval of $0.0018-0.0073 \mathrm{fmol} / 5 \mu \mathrm{l}(0.36-1.46 \mathrm{pm})$. This effect was transient, with latencies returning to preinjection values by 20 min postinjection (Fig. 4) $\left[p<0.05 ; \operatorname{ANOVA}\left(F_{(2,28)}=5.13\right)\right]$. It should be noted that although hyperalgesia was consistently observed at these concentrations, preliminary data suggest that at higher concentrations SR 141716A is not as effective at producing hyperalgesia. The production of hyperalgesia by intrathecal administration of the cannabinoid receptor antagonist in otherwise naive animals is consistent with the hypothesis that spinal cannabinoid receptors act tonically to modulate basal nociceptive thresholds in intact animals.

In addition to the cannabinoid receptor, glutamate is located on certain terminals of the spinal cord (De Biasi and Rustioni, 1988). The release of glutamate from these terminals results in hyperalgesia, in part by interacting with the NMDA glutamate receptor subtype (Aanonsen and Wilcox, 1987). Interestingly, cannabinoids have been reported to presynaptically inhibit the release of glutamate from cultured neurons (Shen et al., 1996). Thus, one potential mechanism for the tonic modulation of basal nociceptive thresholds by cannabinoids is the presynaptic inhibition of basal glutamate release. One prediction of this hypothesis is that the hyperalgesic action of SR 141716A is caused by the disinhibition of glutamate release into the dorsal spinal cord. The possibility that the hyperalgesia mediated by SR 141716 A has an NMDA compo-
A
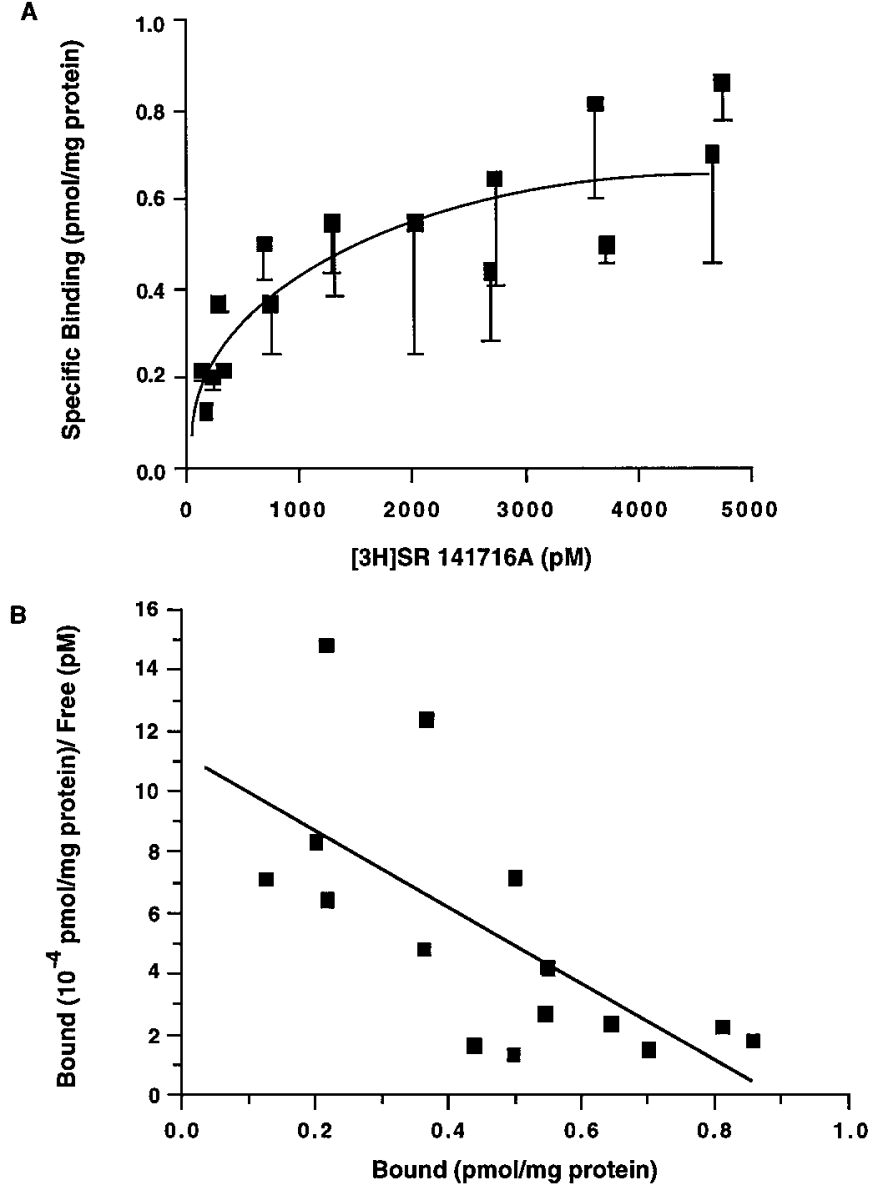

Figure 2. Binding of $\left[{ }^{3} \mathrm{H}\right] \mathrm{SR} 141716 \mathrm{~A}$ to tissue from normal animals. Receptor binding was performed in $\mathrm{P}_{2}$ membranes from mouse lumbar spinal cord using [ $\left.{ }^{3} \mathrm{H}\right] \mathrm{SR} 141716 \mathrm{~A}$. $A$ shows a saturation curve. Error bars are SEM. Error bars that are not visible are contained within the symbol. $B$ shows a Rosenthal (Scatchard) plot of the same data. 


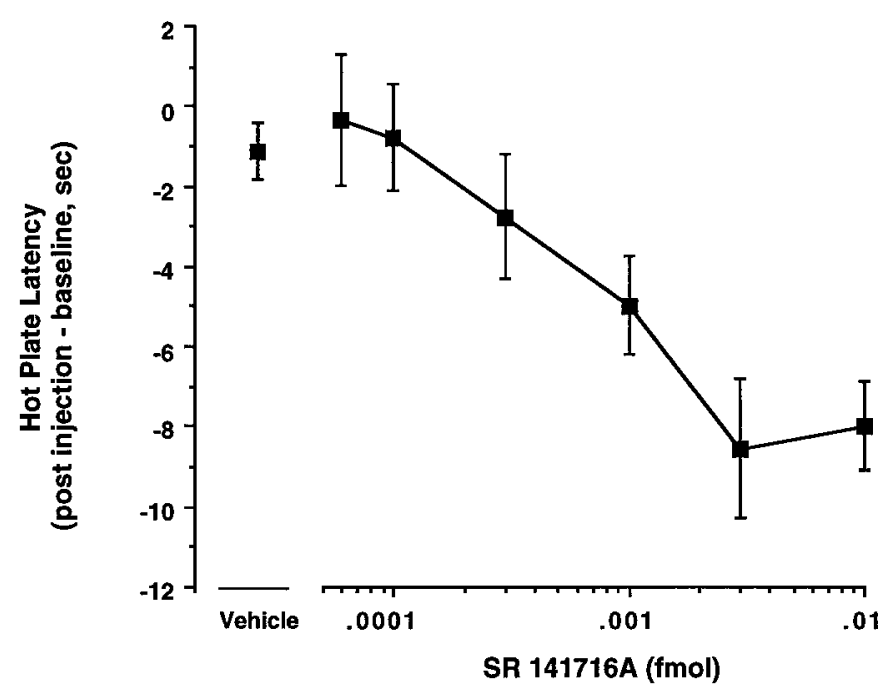

Figure 3. Effect of SR 141716 A on hot plate latencies in normal animals. Mice received a $5 \mu \mathrm{l}$ intrathecal injection of either the saline vehicle $(n=$ 49) or SR 141716A (0.0006-0.01 fmol; $n=10-29)$. Hot plate latencies were measured before and $5 \mathrm{~min}$ after injection. $\mathrm{ED}_{50}=0.0012 \mathrm{fmol}$ $(95 \%$ confidence interval $=0.00018-0.0073 \mathrm{fmol})$. Observers were blind to treatment allocations. Error bars represent SEM.

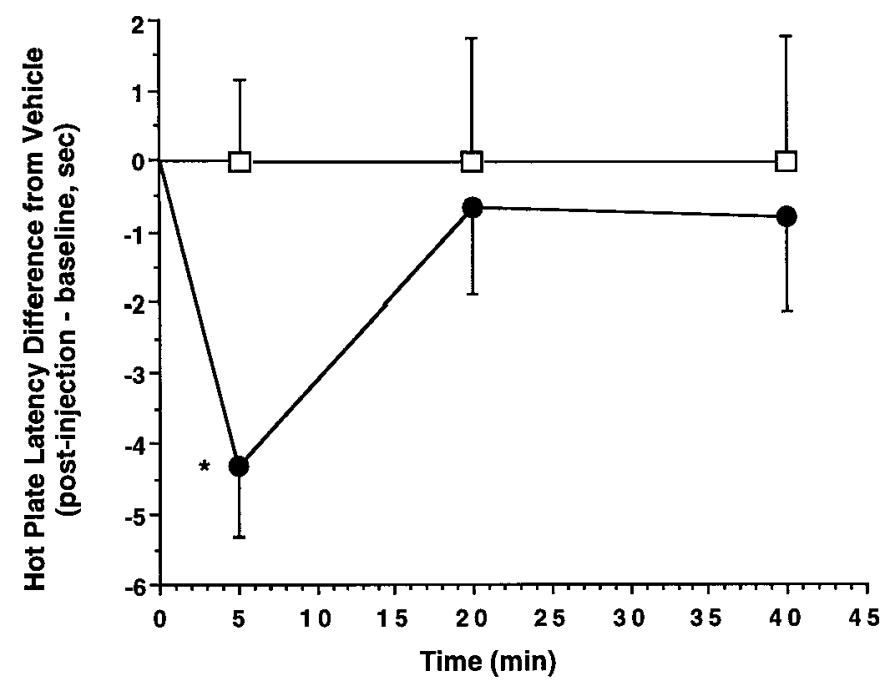

Figure 4. Time course of SR 141716A-induced hyperalgesia. After baseline hot plate latencies were recorded, mice received an intrathecal injection of either saline ( $n=10$; open squares) or $0.005 \mathrm{fmol} \mathrm{SR} 141716 \mathrm{~A}$ $(n=10$; closed circles $)$. Hot plate latencies were again recorded at 5, 20, and 40 min postinjection. Observers were blind to treatment allocation. Error bars are SEM. $p<0.05$; ANOVA with Duncan's multiple range test.

nent was evaluated by intrathecal co-administration of NMDA receptor antagonists with SR 141716A. The results are presented in Figures 5 and 6 . The intrathecal administration of SR 141716A (0.005 fmol/5 $\mu \mathrm{l} ; 1 \mathrm{pM})$ produced a similar degree of thermal hyperalgesia versus that of vehicle-treated animals in four independent experiments $[-6.19 \pm 0.81$ vs $0.01 \pm 0.68 \mathrm{sec}$ (Fig. 5); $p<$ $0.001 ; \operatorname{ANOVA}\left(F_{(5,76)}=12.41\right) ;-5.35 \pm 1.03$ vs $0.00 \pm 0.85 \mathrm{sec}$ (Fig. 6); $p<0.01$; ANOVA $\left(F_{(5,67)}=5.0\right)$; and previous data presented in Figs. 3 and 4]. Co-administration of SR 141716A with the competitive NMDA receptor antagonist D-AP-5 (0.5-5.0 $\mathrm{pmol} / 5 \mu \mathrm{l})$ resulted in a dose-dependent inhibition of SR 141716A-

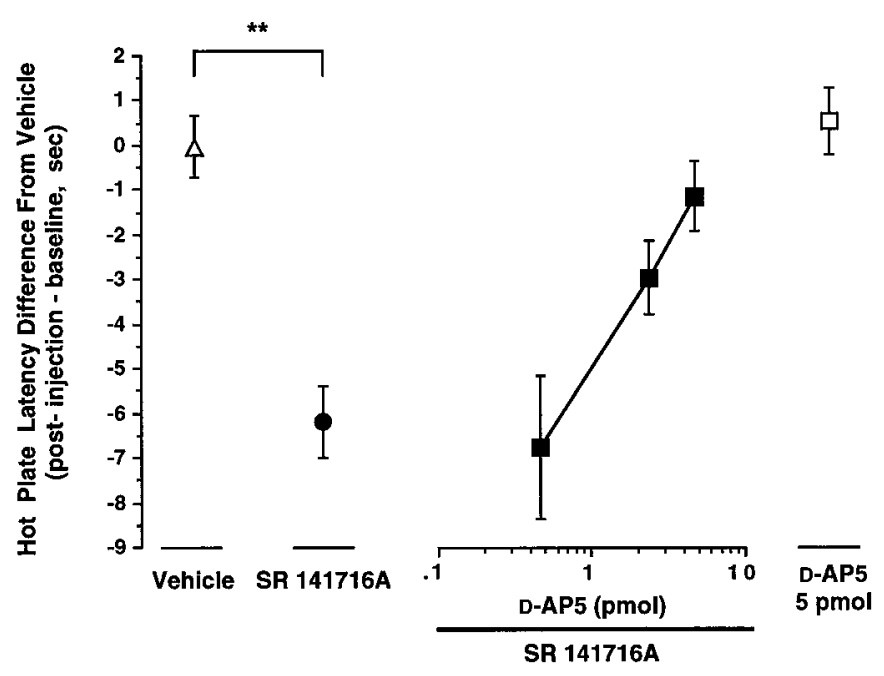

Figure 5. Inhibition of SR 141716A-induced hyperalgesia by the NMDA antagonist D-AP-5. Hot plate latencies were recorded in mice before and 5 min after a $5 \mu$ injection of one of the following: saline vehicle $(n=20$; open triangle), 5.0 pmol D-AP-5 ( $n=11$; open square), or $0.005 \mathrm{fmol} \mathrm{SR}$ $141716 \mathrm{~A}$ in the absence $(n=20$; filled circle $)$ or presence of $0.5 \mathrm{pmol}(n=$ $10), 2.5 \mathrm{pmol}(n=10)$, or $5.0 \mathrm{pmol}(n=11) \mathrm{D}-\mathrm{AP}-5$ ( filled squares). Data are normalized to the vehicle control. Observers were blind to treatment allocations. Error bars are SEM. ${ }^{* *} p<0.01$ versus vehicle $\left(F_{(5,76)}=\right.$ 12.41); $p<0.001$; ANOVA with Duncan's multiple range test.

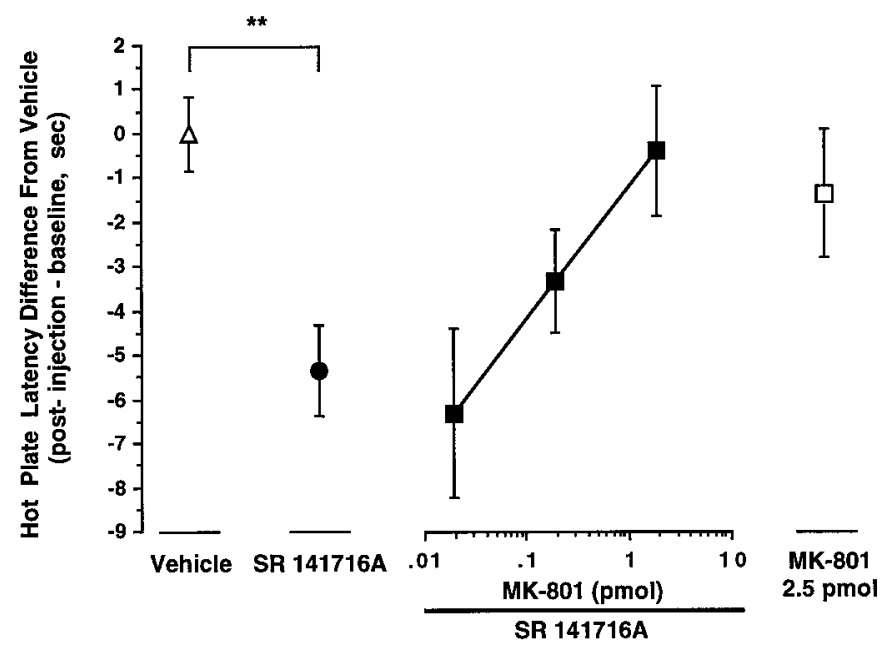

Figure 6. Inhibition of SR 141716A-induced hyperalgesia by the NMDA antagonist MK-801. Hot plate latencies were recorded in mice before and $5 \mathrm{~min}$ after a $5 \mu \mathrm{l}$ intrathecal injection of one of the following: saline vehicle ( $n=20$; open triangle), 2.5 pmol MK-801 ( $n=9$; open square), or $0.005 \mathrm{fmol}$ SR $141716 \mathrm{~A}$ in the absence $(n=20$; filled circle) or presence of 0.025 pmol $(n=9), 0.25$ pmol $(n=7)$, or 2.5 pmol $(n=8)$ MK-801 (filled squares). Data are normalized to the vehicle control. Observers were blind to treatment allocations. Error bars are SEM. ${ }^{* *} p<0.01$ versus vehicle $\left(F_{(5,67)}=4.95\right) ; p<0.001$; ANOVA with Duncan's multiple range test.

induced hyperalgesia [(Fig. 5) $p<0.001$; ANOVA/linear regression $\left.\left(F_{(1,29)}=12.87\right)\right]$. The maximal inhibition was observed at 5 pmol D-AP-5, at which concentration latencies had returned to preinjection values $(-1.14 \pm 0.79$ vs $0.01 \pm 0.68 \mathrm{sec})$. Application of D-AP-5 in the absence of SR 141716A had no effect on hot plate latencies when compared with controls $(0.52 \pm 0.76$ vs $0.01 \pm 0.68$ $\mathrm{sec})$.

To eliminate the possibility of a nonselective interaction be- 
tween SR 141716A and D-AP-5, the effect of the noncompetitive NMDA receptor antagonist MK-801 was also evaluated (Fig. 6). At concentrations of $0.025-2.5$ pmol, co-administration of MK801 with SR 141716A also dose-dependently inhibited SR 141716A-induced hyperalgesia [ $p<0.05$; ANOVA/linear regres$\left.\operatorname{sion}\left(F_{(1,22)}=7.5\right)\right]$. Maximal inhibition was observed at $2.5 \mathrm{pmol}$ MK-801; at this concentration there was no difference from the vehicle control $(-0.40 \pm 1.5$ vs $0.00 \pm 0.85 \mathrm{sec})$. Additionally, at its highest concentration, MK-801 showed no effect on its own $(-1.37 \pm 1.45 \mathrm{vs} 0.00 \pm 0.85 \mathrm{sec})$ when compared with the vehicle control. Together, these results comprise four independent replicates of SR 141716A-induced hyperalgesia and indicate that it is mediated by an NMDA receptor mechanism.

\section{DISCUSSION}

In the present studies we have evaluated the hypothesis that the spinal cannabinoid system modulates basal thermal nociceptive thresholds. Our first study indicates that decreasing cannabinoid receptor density in the lumbar but not cervical spinal cord results in hyperalgesia. After $4 \mathrm{~d}$ of administration of an oligonucleotide complementary to the $\mathrm{CB}_{1}$ receptor mRNA, there was a decrease in cannabinoid receptor binding, as determined with $\left[{ }^{3} \mathrm{H}\right] \mathrm{CP}$ 55,940 , when compared with binding from the tissue of animals receiving the randomer control. The antisense oligonucleotide is not complementary to any known mRNA (Edsall et al., 1996). Because of the specificity, it is reasonable to assume that the decrease in binding observed after treatment with the antisense oligonucleotide was caused by a decrease in the $\mathrm{CB}_{1}$ subtype of cannabinoid receptors. However, the magnitude of reduction in $\mathrm{CB}_{1}$ binding sites cannot be determined because $\left[{ }^{3} \mathrm{H}\right] \mathrm{CP} 55,940$ is not selective for the $\mathrm{CB}_{1}$ receptor over the $\mathrm{CB}_{2}$ receptor. The binding sites remaining after treatment with the antisense oligonucleotide may therefore be either $\mathrm{CB}_{1}$ or $\mathrm{CB}_{2}$ receptors. However, the presence of $\mathrm{CB}_{2}$ receptors in spinal cord has not been reported in the literature. Our results indicate that there is little difference in the amount of binding determined with $\left[{ }^{3} \mathrm{H}\right] \mathrm{CP}$ 55,940 or the selective $\mathrm{CB}_{1}$ receptor antagonist $\left[{ }^{3} \mathrm{H}\right] \mathrm{SR} 141716 \mathrm{~A}$, suggesting that if $\mathrm{CB}_{2}$ receptors are located in rat spinal cord, they are expressed at a very low density. Thus, assuming that only $\mathrm{CB}_{1}$ receptors were labeled with $\left[{ }^{3} \mathrm{H}\right] \mathrm{CP} 55,940$, the reduction in $\mathrm{CB}_{1}$ receptors was $61 \%$.

Animals receiving the antisense oligonucleotide treatment displayed significant hyperalgesia on the day after termination of treatment, the same day at which the decrease in cannabinoid receptor binding was measured. A similar treatment regimen with the same oligonucleotide sequences administered intracerebroventricularly had no effect on basal hot plate latencies but did result in a shift to the right in the dose-response curve for intracerebroventricular cannabinoid-induced antinociception (Edsall et al., 1996). In that study, cannabinoid receptor levels were not determined, and thus there is no way of knowing at which regions and to what extent the oligonucleotides were effective in reducing cannabinoid receptor densities. Our results indicate that administration of the oligonucleotide to the lumbar enlargement produced a very localized effect, i.e., not even extending to the cervical enlargement. Taken together, these studies suggest that tonic modulation of nociceptive thresholds by cannabinoid receptors is not a ubiquitous event but rather may be localized to the lumbar enlargement of the spinal cord.

Our subsequent studies independently evaluated the hypothesis of regulation of basal thermal nociceptive thresholds by cannabinoid receptors by intrathecal administration of SR 141716A.
SR $141716 \mathrm{~A}$ is a selective, high-affinity antagonist at the $\mathrm{CB}_{1}$ receptor that demonstrates a $K_{\mathrm{i}}$ for the transfected $\mathrm{CB}_{1}$ receptor of $12 \pm 2 \mathrm{~nm}$ but only $973 \pm 280 \mathrm{nM}$ for the transfected $\mathrm{CB}_{2}$ receptor (Felder et al., 1995). We found that the $K_{\mathrm{d}}$ of $\left[{ }^{3} \mathrm{H}\right] \mathrm{SR}$ $141716 \mathrm{~A}$ in mouse lumbar spinal cord was $600 \pm 200 \mathrm{pm}$, which is similar to what has been reported for rat whole brain synaptosomes $(610 \pm 60 \mathrm{pm})$ (Rinaldi-Carmona et al., 1996) and rat cerebellum $(610 \pm 120 \mathrm{pm})$ (Hirst et al., 1996). The $\mathrm{IC}_{50}$ of SR $141716 \mathrm{~A}$ at 35 noncannabinoid receptors, including the NMDA receptor, is $>1 \mu \mathrm{M}$ (Rinaldi-Carmona et al., 1994). Together, available data indicate that $\mathrm{SR} 141716 \mathrm{~A}$ is selective for the $\mathrm{CB}_{1}$ receptor. Thus it was used to evaluate the involvement of $\mathrm{CB}_{1}$ receptors in modulation of basal nociceptive thresholds. Our results indicate that SR 141716 A was very potent in producing hyperalgesia. In addition, its ability to produce hyperaglesia was short-lived, lasting $<20 \mathrm{~min}$. It is interesting that this time course is similar to that observed after intrathecal administration of NMDA (Aanonsen and Wilcox, 1987). The short time course of SR 141716A hyperalgesia may reflect the diffusion from the active receptors, which appear to be located discretely in the lumbar enlargement, or redistribution of the highly lipophilic SR 141716A. Alternatively, it may be secondary to depletion of releasable glutamate or a short time course of glutamate activity at NMDA receptors. The transience of the effect argues against neurotoxicity of the drug and supports the hypothesis that SR 141716A inhibits tonic activity of the cannabinoid receptor and in this way produces hyperalgesia.

It is curious that the $\mathrm{ED}_{50}$ for SR $141716 \mathrm{~A}(0.24 \mathrm{pM})$ is well below the determined $K_{\mathrm{d}}$ for SR $141716 \mathrm{~A}$ in mouse lumbar spinal cord $(600 \mathrm{pM})$. The reason for this difference is currently unclear. One possibility is that SR $141716 \mathrm{~A}$ is interacting with high affinity at a noncannabinoid binding site. However, if this were the case, we would not have expected hyperalgesia after treatment with the $\mathrm{CB}_{1}$ antisense oligonucleotide. Another possibility is that a lowdensity, high-affinity $C_{1}$ receptor subtype is present in spinal cord and its detection is difficult with current ligands. The selectivity of SR 141716A for the $\mathrm{CB}_{1}$ receptor together with the hyperalgesia obtained after the $\mathrm{CB}_{1}$ receptor knockdown support the involvement of the $\mathrm{CB}_{1}$ receptor in modulation of basal nociceptive thresholds.

An alternative explanation must be considered for the effects of the $\mathrm{CB}_{1}$ receptor knockdown and $\mathrm{SR} 141716 \mathrm{~A}$ on hot plate latencies. Along with antinociception, two classic behavioral responses to cannabinoid agonist administration are catalepsy and hypomotility. Thus, it is possible that the shorter latencies observed after SR 141716A and $\mathrm{CB}_{1}$ antisense oligonucleotide treatment may be caused by increased locomotor activity rather than hyperalgesia. There are two arguments against this possibility. First, Yaksh (1981) demonstrated that at concentrations necessary to produce antinociception, intrathecally administered cannabinoids did not produce any detectable changes in motor activity. Catalepsy was observed only at concentrations four times the $\mathrm{ED}_{50}$ for producing antinociception and only after a delay, suggesting that nociceptive thresholds are more sensitive to intrathecal administration of cannabinoids than are the locomotor effects. Indeed, in the present study, blinded observers were unable to detect differences in gross locomotor activity among the treatment groups. Second, Compton and colleagues (1996) report that intravenous SR 141716A is capable of stimulating locomotor activity. However, these effects are seen only at concentrations $>3 \mathrm{mg} / \mathrm{kg}(\sim 0.137 \mu \mathrm{mol})$. This dose is 20 -fold greater than dosages required to block cannabinoid-induced antinociception 
in the same studies. Together, these support the hypothesis that the decreased latencies reflect changes in nociceptive transmission rather than locomotion.

Collectively, these studies support the hypothesis that tonic activity at the spinal $\mathrm{CB}_{1}$ receptor maintains thermal nociceptive thresholds. Tonic activity of the cannabinoid receptor has been reported previously in a different model: SR 141716A enhances short-term memory in rats and mice, suggesting that the cannabinoid system tonically modulates memory (Terranova et al., 1996). Tonic activity of receptors can be explained either by the activation of the receptor by an endogenous ligand or by the spontaneous coupling between the receptor and G-protein in the absence of ligand (Costa et al., 1992). Although the latter occurs in cell expression systems, it has not been reported in vivo, suggesting that there may be tonic release of endogenous cannabinoids in the spinal cord.

In the present study, tonic activity of the spinal cannabinoid receptor under basal conditions was demonstrated by the hyperalgesia induced by a decrease in cannabinoid receptor density and by administration of the cannabinoid receptor antagonist. Thus, tonic spinal cannabinoid receptor activation results in the modulation of basal thermal nociceptive thresholds. The mechanism for such modulation may be similar to the mechanism of antinociception produced by the exogenous administration of cannabinoids. Although the mechanism for spinal cannabinoid-induced antinociception has not been determined, several lines of evidence are consistent with it involving the inhibition of neurotransmitter release. Activation of the $\mathrm{CB}_{1}$ receptor inhibits adenylyl cyclase activity (Howlett, 1984), which has been implicated in the regulation of exocytosis (Chavez-Noriega and Stevens, 1994). Additionally, $\mathrm{CB}_{1}$ activation can close certain calcium channels whose activity is necessary for neurotransmitter release (Mackie and Hille, 1992; Caulfield and Brown, 1992). Finally, $\mathrm{CB}_{1}$ activation can enhance potassium currents that can lead to hyperpolarization of the membrane (Deadwyler et al., 1993; Henry and Chavkin, 1995). Thus, the mechanism for cannabinoid antinociception may be the inhibition of the release of neurotransmitters involved in nociception, such as glutamate. Inhibition of such cannabinoid activity would result in glutamate release and potentially NMDA receptor activation and hyperalgesia. In support of this hypothesis, SR 141716A-induced hyperalgesia could be inhibited by both the competitive NMDA antagonist D-AP-5 and the noncompetitive NMDA antagonist MK-801. These results support the hypothesis that SR 141716A-induced hyperalgesia is attributable to disinhibition of glutamate release.

Collectively, these results are consistent with the hypothesis that the endogenous spinal cannabinoid system modulates basal thermal nociceptive thresholds. These studies demonstrate that a decrease in cannabinoid receptor number in the lumbar spinal cord is correlated with hyperalgesia and that inhibition of cannabinoid activation by administration of a cannabinoid receptor antagonist results in an NMDA-dependent hyperalgesia. A recent report demonstrates that intrathecal administration of pertussis toxin, which inactivates $G_{i}$ and $G_{o}$ proteins via ADP ribosylation, will produce hyperalgesia in mice (Womer et al., 1997). The results from the present study suggest that one potential mechanism by which pertussis toxin may act to produce hyperalgesia is by inactivating spinal cannabinoid receptors. Taken together, these results provide a strong rationale for the hypothesis that hypoactivity of the cannabinoid system may be involved in the etiology of certain chronic pain states. Because opioids are not thought to be involved in modulation of basal nociceptive thresholds, these findings provide a major difference between these two endogenous analgesic systems. Thus, there may be pain states that are unresponsive to opioids but are relieved by administration of cannabinoids. In animals, this is the case with neuropathic pain that responds poorly to opioids but has recently been demonstrated to be sensitive to cannabinoids (Herzberg et al., 1997). Accordingly, drugs that activate cannabinoid receptors or gene therapy directed at increasing activity of the cannabinoid system may have therapeutic use in treating certain types of chronic pain.

\section{REFERENCES}

Aanonsen LM, Wilcox GL (1987) Nociceptive action of excitatory amino acids in the mouse: effects of spinally administered opioids, phencyclidine and sigma agonists. J Pharmacol Exp Ther 243:9-19.

Besson J-M, Chaouch A (1987) Peripheral and spinal mechanisms of nociception. Pharmacol Rev 67:67-186.

Caulfield MP, Brown DA (1992) Cannabinoid receptor agonists inhibit $\mathrm{Ca}^{2+}$ current in NG108-15 neuroblastoma cells via a pertussis toxinsensitive mechanism. Br J Pharmacol 106:231-232.

Chavez-Noriega LE, Stevens CF (1994) Increased transmitter release at excitatory synapses produced by direct activation of adenylate cyclase in rat hippocampal slices. J Neurosci 14:310-317.

Compton DR, Aceto MD, Lowe J, Martin BR (1996) In vivo characterization of a specific cannabinoid receptor antagonist (SR 141716A): inhibition of $\Delta^{9}$-tetrahydrocannabinol-induced responses and apparent agonist activity. J Pharmacol Exp Ther 277:586-594.

Costa T, Ogino Y, Munson PJ, Onaran HO, Rodbard D (1992) Drug efficacy at guanine nucleotide-binding regulatory protein-linked receptors: thermodynamic interpretation of negative antagonism and of receptor activity in the absence of ligand. Mol Pharmacol 41:549-560.

Deadwyler SA, Hampson RE, Bennett BA, Edwards TA, Mu J, Pacheco MA, Ward SJ, Childers SR (1993) Cannabinoids modulate potassium current in cultured hippocampal neurons. Receptors Channels 1:121-134.

De Biasi S, Rustioni A (1988) Glutamate and substance P coexist in primary afferent terminals in the superficial laminae of spinal cord. Proc Natl Acad Sci USA 85:7820-7824.

Devane WA, Dysarz FA, Johnson MR, Melvin LS, Howlett AC (1988) Determination and characterization of a cannabinoid receptor in rat brain. Mol Pharmacol 34:605-613.

Edsall SA, Knapp RJ, Vanderah TW, Roeske WR, Consroe P, Yamamura HI (1996) Antisense oligodeoxynucleotide treatment to the brain cannabinoid receptor inhibits antinociception. NeuroReport 7:593-596.

Felder CC, Joyce KE, Briley EM, Mansouri J, Mackie K, Blond O, Lai Y, Ma A, Mitchell RA (1995) Comparison of the pharmacology and signal transduction of the human cannabinoid $\mathrm{CB}_{1}$ and $\mathrm{CB}_{2}$ receptors. Mol Pharmacol 48:443-450.

Gifford AN, Ashby CR (1996) Electrically evoked acetylcholine release from hippocampal slices is inhibited by the cannabinoid receptor agonist, WIN 55212-2, and is potentiated by the cannabinoid antagonist SR 141716A. J Pharmacol Exp Ther 277:1431-1436.

Henry DJ, Chavkin C (1995) Activation of inwardly rectifying potassium channels (GIRK1) by co-expressed rat brain cannabinoid receptors in Xenopus oocytes. Neurosci Lett 186:91-94.

Herkenham M, Lynn AB, Johnson MR, Melvin LS, de Costa BR, Rice KC (1991) Characterization and localization of cannabinoid receptors in rat brain: a quantitative in vitro autoradiographic study. J Neurosci 11:563-583.

Herzberg U, Eliav E, Bennett GJ, Kopin IJ (1997) The analgesic effects of R(+)WIN 55,212-2 mesylate, a high affinity cannabinoid agonist, in a rat model of neuropathic pain. Neurosci Lett 221:157-160.

Hirst RA, Almond SL, Lambert DG (1996) Characterization of the rat cerebella CB1 receptor using SR 141716A, a central cannabinoid receptor antagonist. Neurosci Lett 220:101-104.

Hohmann AG, Martin WJ, Tsou K, Walker JM (1995) Inhibition of noxious stimulus-evoked activity of spinal cord dorsal horn neurons by the cannabinoid WIN 55,212-2. Life Sci 56:2111-2118.

Howlett AC (1984) Inhibition of neuroblastoma adenylate cyclase by cannabinoid and nantradol compounds. Life Sci 35:1803-1810.

Hylden JLK, Wilcox GL (1980) Intrathecal morphine in mice: a new technique. Eur J Pharmacol 67:313-316. 
Ishac EJN, Jiang L, Lake KD, Varga K, Abood ME, Kunos G (1996) Inhibition of exocytotic noradrenaline release by presynaptic cannabinoid $\mathrm{CB}_{1}$ receptors on peripheral sympathetic nerves. Br J Pharmacol 118:2023-2028.

Lichtman AH, Martin BR (1991) Spinal and supraspinal components of cannabinoid-induced antinociception. J Pharmacol Exp Ther 258: 517-523.

Mackie K, Hille B (1992) Cannabinoids inhibit N-type calcium channels in neuroblastoma-glioma cells. Proc Natl Acad Sci USA 89:3825-3829.

Rinaldi-Carmona M, Barth F, Heaulme M, Shire D, Calandra B, Congy C, Martinez S, Maruani J, Neliat G, Caput D, Ferrara P, Soubrie P, Breliere JC, Le Fur G (1994) SR 141716A, a potent and selective antagonist of the brain cannabinoid receptor. FEBS Lett 350:240-244.

Rinaldi-Carmona M, Pialot F, Congy C, Redon E, Barth F, Bachy A, Breliere J-C, Soubrié P, Le Fur G (1996) Characterization and distribution of binding sites for $\left[{ }^{3} \mathrm{H}\right] \mathrm{SR} 141716 \mathrm{~A}$, a selective brain $\left(\mathrm{CB}_{1}\right)$ cannabinoid receptor antagonist, in rodent brain. Life Sci 15:1239-1247.

Shen M, Piser TM, Seybold VS, Thayer SA (1996) Cannabinoid recep- tor agonists inhibit glutamatergic synaptic transmission in rat hippocampal cultures. J Neurosci 16:4322-4334.

Sora I, Takahashi N, Funada M, Ujike H, Revay RS, Donovan DM, Miner LL, Uhl GR (1997) Opiate receptor knockout mice define mu receptor roles in endogenous nociceptive responses and morphine-induced analgesia. Proc Natl Acad Sci USA 94:1544-1549.

Terranova J-P, Storme J-J, Lafon N, Perio A, Rinaldi-Carmona M, Le Fur G, Soubrie P (1996) Improvement of memory in rodents by the selective $\mathrm{CB}_{1}$ cannabinoid receptor antagonist, SR 141716A. Psychopharmacology (Berl) 126:165-172.

Tsou K, Lowitz KA, Hohmann AG, Martin WJ, Hathaway CB, Bereiter DA, Walker JM (1996) Suppression of noxious stimulus-evoked expression of fos protein-like immunoreactivity in rat spinal cord by a selective cannabinoid agonist. Neuroscience 70:791-798.

Womer DE, DeLapp NW, Shannon HE (1997) Intrathecal pertussis toxin produces hyperalgesia and allodynia in mice. Pain 70:223-228.

Yaksh TL (1981) The antinociceptive effects of intrathecally administered levonantradol and desacetyllevonantradol in the rat. J Clin Pharmacol 21:334S-340S. 